\author{
Agnieszka SMARZEWSKA ${ }^{1}$ \\ Ewelina MELANIUK ${ }^{2}$ \\ Agnieszka DYMICKA ${ }^{3}$ \\ Adam SZEPELUK ${ }^{4}$
}

\title{
KSZTAŁTOWANIE BEZPIECZEŃSTWA ZAWODOWEGO ABSOLWENTÓW
}

\begin{abstract}
Szanse na znalezienie pracy wzrastają wraz z ukończeniem studiów wyższych. Zapewnienie bezpieczeństwa zawodowego absolwentom stanowi jedno z podstawowych działań kształtowanych przez bezpieczeństwo edukacyjne. Monitorowanie karier zawodowych absolwentów jest pożądanym działaniem szkoły, przekładającym się na aktualizację realizowanej strategii. Celem artykułu jest dokonanie analizy sytuacji absolwentów uczelni po ukończeniu kształcenia na poziomie studiów wyższych I i II stopnia. Efektem badań jest stwierdzenie, że wykształcenie wyższe zwiększa szanse na zatrudnienie, a realizowany w trakcie studiów program kształcenia umożliwia właściwe przygotowanie do wejścia na rynek pracy. Badania potwierdziły, iż stopień ukończonych studiów jest czynnikiem różnicującym szanse zawodowe absolwentów uczelni. Przedstawione wnioski kształtują pozytywną opinię absolwentów w zakresie wszystkich obszarów objętych badaniami, potwierdzając tym samym poprawność prowadzonej polityki uczelni i działań budujących bezpieczeństwo edukacyjne. Ponad $80 \%$ absolwentów jest przekonanych o właściwym przygotowaniu do pracy zawodowej. Główną zaletą zdobytego wykształcenia zdaniem absolwentów jest wzrost szans na rynku pracy. Absolwenci zastrzegają konieczność ulepszania oferty edukacyjnej, społecznej i kulturalnej uczelni, głównie poprzez organizację spotkań z ciekawymi ludźmi, kursów językowych oraz wycieczek naukowych/studyjnych. Prezentowane wyniki badań są zatem częścią cyklu badawczego z zakresu bezpieczeństwa edukacyjnego, uwzględniającego szereg tworzących je elementów, m.in. badania studentów I roku w zakresie wyboru uczelni oraz kierunku studiów, badania opinii pracodawców pod kątem oceny studentów odbywających praktyki zawodowe czy monitoringu karier zawodowych absolwentów.
\end{abstract}

Słowa kluczowe: bezpieczeństwo, absolwent, rynek pracy, stopień studiów.

\section{WPROWADZENIE}

Bezpieczeństwo zawodowe jest efektem prawidłowo kształtowanego bezpieczeństwa edukacyjnego, traktowanego jako zapewnienie uczniom/studentom/absolwentom rozwoju i bezpieczeństwa w zakresie edukacji na poziomie szkoły czy studiów wyższych oraz efek-

1 Dr inż. Agnieszka Smarzewska, Katedra Ekonomii i Zarządzania, Państwowa Szkoła Wyższa im. Papieża Jana Pawała II w Białej Podlaskiej, ul. Sidorska 95/97, 21-500 Biała Podlaska, tel. 833449944; e-mail: a.smarzewska@pswbp.pl

2 Mgr inż. Ewelina Melaniuk, PSW im. Papieża Jana Pawła II w Białej Podlaskiej.

3 Mgr Agnieszka Dymicka, PSW im. Papieża Jana Pawła II w Białej Podlaskiej.

4 Mgr Adam Szepeluk, PSW im. Papieża Jana Pawła II w Białej Podlaskiej. 
tywnego funkcjonowania szkoły/uczelni (instytucji) w jej ustawowym oraz statutowym zakresie. Uzyskany dyplom czy świadectwo potwierdzają zdobyty przez absolwenta zawód i rozwinięte kompetencje, stanowiąc dokument zakończenia edukacji na określonym poziomie. Bezpieczeństwo człowieka jest więc ściśle związane z jego rozwojem edukacyjnym, a w konsekwencji zawodowym ${ }^{5}$.

Losy absolwentów uczelni wyższych, a w szczególności ich trajektorie na rynku pracy, są jednym z najistotniejszych i najszerzej dyskutowanych problemów w kraju6. Dostęp do rzetelnych wyników ogólnopolskich badań na temat przebiegu studiowania czy zapotrzebowania pracodawców na absolwentów konkretnych kierunków studiów, w tym posiadających określone umiejętności, z pewnością ułatwi dokonywanie wyborów edukacyjnych i zawodowych przez kandydatów na studia, studentów oraz absolwentów.

Prognozy demograficzne Głównego Urzędu Statystycznego do 2035 r., poparte statystykami demograficznymi, wskazują na znaczny spadek liczby urodzeń, pociągający za sobą systematyczne zmniejszanie się ludności Polski ${ }^{7}$. Sytuacja budzi zatem zainteresowanie nie tylko demografów, ale przekłada się w znaczny sposób na podejmowanie prób kreowania polityki państwa w odniesieniu do wielu sfer życia społecznego, ekonomicznego, gospodarczego, a także interesującego Autorów opracowania, edukacyjnego. Prognozowanie demograficzne nie napawa bowiem optymizmem.

W roku akademickim 2013/2014 działało w Polsce 438 szkół wyższych, kształcących łącznie 1549900 osób $^{8}$. Wiele uczelni, wśród których znajdują się zarówno te o krótszych doświadczeniach akademickich, jak i te z tradycjami uniwersyteckimi, staje w obliczu sytuacji, na którą nie ma bezpośredniego wpływu. Jednym z rozwiązań pozostaje zatem wypracowanie takich mechanizmów, które pozwolą uczelniom wyższym stworzyć ciekawą jakościowo i skorelowaną z potrzebami rynku pracy ofertę edukacyjną. Narzędzia, które w znaczny sposób mogą usprawnić i nadać właściwy kierunek polityce edukacyjnej poszczególnym uczelniom zostały opracowane w ramach wewnętrznych systemów zapewnienia jakości kształcenia ${ }^{9}$. Jednym z ważnych ogniw przybliżających studentom rynek pracy, stwarzających możliwość zdobywania dodatkowych umiejętności podczas szkoleń, kursów, praktyk czy staży, jak również umożliwiających kontakt z pracodawcami poprzez organizację różnego rodzaju eventów, są działające w uczelniach akademickie biura karier ${ }^{10}$.

Dążenie do znacznej kompatybilności rynku usług edukacyjnych z rynkiem pracy przyczyniło się do wypracowania narzędzi, służących rozwojowi tego procesu, nakładając na uczelnie ustawowy obowiązek monitorowania karier zawodowych swoich absolwentów.

5 A. Smarzewska, E. Melaniuk, Wptyw oceny na dyplomie na możliwość zatrudnienia absolwentów kierunku Bezpieczeństwo Narodowe, Rozprawy Społeczne 2014, nr 4 (VIII), s. 43.

6 Pracownia Ewaluacji Jakości Kształcenia Uniwersytetu Warszawskiego, Monitorowanie losów absolwentów uczelni wyższych z wykorzystaniem danych administracyjnych Zakładu Ubezpieczeń Spotecznych. Raport końcowy, Warszawa 2014, s. 110-111.

7 CBOS, Postawy prokreacyjne Polaków BS/4/2010, Warszawa 2010, s. 1.

8 CBOS, Studia wyższe - dla kogo, po co i z jakim skutkiem BS/92/2013, Warszawa 2013, s. 1-4.

9 M. Próchnicka, Zeszyt dobrych praktyk dotyczących wewnętrznego zapewnienia jakości ksztatcenia w uczelniach, Fundacja Rozwoju Systemu Edukacji, Warszawa 2013, s. 11; D. Piotrowska, M. Ziółek, Wewnętrzne systemy zapewnienia jakości ksztatcenia w odniesieniu do nowych regulacji prawnych, Łódź 2012, http://ekspercibolonscy.org.pl (dostęp: 08.07.2015 r.).

${ }^{10}$ Rzecznik Praw Absolwenta, Akademickie Biura Karier w Polsce bieżaca działalność i możliwości rozwoju, Warszawa 2014, s. 9-15, 25, 35. 
W zamyśle zapis miał za zadanie dostosowanie kierunków studiów, a zarazem programów kształcenia do wymagań rynku pracy. Założeniem ustawowym była kontynuacja tego badania po trzech i pięciu latach od ukończenia studiów ${ }^{11}$.

Nowelizacja ustawy Prawo o szkolnictwie wyższym z 2014 roku proponuje uczelniom fakultatywne podejście do monitorowania karier zawodowych swoich absolwentów. Można jednak wnosić, iż informacja o utrzymaniu monitoringu będzie stanowiła jeden z atutów uczelni, zauważanych przez Polską Komisję Akredytacyjną, podkreślających dbałość o właściwe modyfikowanie programów kształcenia. Obowiązek zaś prowadzenia tego monitoringu został przypisany ministrowi nauki i szkolnictwa wyższego w odniesieniu do danych gromadzonych przez Zakład Ubezpieczeń Społecznych. Ustawa określa również, jaki rodzaj informacji będzie monitorowany oraz precyzuje terminy monitoringu. Raport zawierający zgromadzone wyniki będzie publikowany na stronie internetowej urzędu obsługującego ministra właściwego do spraw szkolnictwa wyższego ${ }^{12}$.

Zgodnie z wnioskami sformułowanymi przez Ministerstwo Pracy i Polityki Społecznej ${ }^{13}$,czas pozostawania bez pracy wzrasta wraz $\mathrm{z}$ wiekiem bezrobotnych i obniża się wraz z podnoszeniem się poziomowy kształcenia”- należy więc zaproponować sposób prowadzenia polityki edukacyjnej ściśle powiązany z potrzebami rynku pracy, co wpisuje się w budowanie bezpieczeństwa zawodowego absolwentów. Celem poznania trendów zachodzących na tym rynku wykonywane są badania ilościowe i jakościowe, którymi coraz częściej zostają objęci pracodawcy. Odnoszą się oni do kluczowych oczekiwań w zakresie posiadanych kompetencji kandydatów do pracy, wśród których za najbardziej pożądane uznali kompetencje kognitywne, interpersonalne i artystyczne ${ }^{14}$.

Odpowiedzi na pytanie, jak wygląda sytuacja absolwentów uczelni wyższych województwa lubelskiego dostarczają raporty przygotowane przez Lubelskie Obserwatorium Rynku Pracy WUP w Lublinie. Wyniki tych badań w dużej mierze pokrywają się z tendencjami zaobserwowanymi na rynku krajowym, gdzie większość dość nisko ocenia swoje szanse na znalezienie pracy zgodnej z ukończonym kierunkiem studiów. Ten aspekt stanowi również punkt odniesienia absolwentów w formułowaniu satysfakcji z ukończonych studiów, gdzie jednym z głównych wskaźników jest odniesienie jej do możliwości znalezienia pracy zgodnej z wykształceniem ${ }^{15}$. Badaniem objęto również kluczowe kompetencje, które zostały wskazane przez pracujących absolwentów jako najbardziej istotne dla uzyskania zatrudnienia, czyli w procesie rekrutacji. Najwyższe miejsce zajęły takie kompetencje

${ }^{11}$ Ustawa z dnia 18 marca 2011 r. o zmianie ustawy - Prawo o szkolnictwie wyższym, ustawy o stopniach naukowych i tytule naukowym oraz o stopniach i tytule w zakresie sztuki oraz o zmianie niektórych innych ustaw (Dz.U. nr 84, poz. 455) - art.13a.

12 Ustawa z dnia 11 lipca 2014 r. o zmianie ustawy - Prawo o szkolnictwie wyższym oraz niektórych innych ustaw (Dz.U. z 2014 r., poz.1198 ze zm.) - art. 13b, art. 170c.

${ }_{13}$ Ministerstwo Pracy i Polityki Społecznej, Sytuacja na rynku pracy osób młodych w 2014 roku, Warszawa 2014, s. 3.

${ }^{14}$ Ministerstwo Pracy i Polityki Społecznej, Zawody deficytowe i nadwyżkowe w 2014 roku, Warszawa 2015.

${ }^{15}$ P. Krzesiński, Dziś - przemyślany wybór kierunku studiów, w przyszłości - większa szansa na dobra pracę, Biuletyn Informacyjny Wojewódzkiego Urzędu Pracy w Lublinie „Lubelskie na rynku pracy", nr 3/12, Lublin 2014, s. 4-5. 
jak: komunikatywność, sumienność i dokładność, zaangażowanie, samodzielność, organizacja pracy, branie odpowiedzialności czy odporność na stres ${ }^{16}$.

Przytoczone wyniki są przedmiotem analiz podejmowanych przez uczelnie wyższe. Nawiązywanie stałej współpracy z pracodawcami służy wypracowaniu praktycznych modeli w postaci udziału pracodawców w modyfikowaniu programów kształcenia, czy inspirowaniu uczelni wyższych do wykształcania wśród studentów pożądanych kompetencji ${ }^{17}$. Stanowi to efekt podejmowanych działań w zakresie bezpieczeństwa edukacyjnego, które posiada dualny charakter. Z perspektywy uczelni jest to realizacja statutowych działań, zaś ze strony studenta/absolwenta zaspokajanie potrzeb rozwoju osobistego, zawodowego i naukowego, a w konsekwencji sukcesu na rynku pracy w postaci zatrudnienia ${ }^{18}$.

W związku z faktem, iż szanse zatrudnienia wzrastają wraz z przejściem z kategorii posiadania tytułu licencjata (63,8\% osób aktywnych zawodowo) do osoby posiadającej tytuł magistra $(80,7 \%)$ można stwierdzić, iż czynnikiem różnicującym szanse zawodowe absolwentów uczelni jest stopień ukończonych studiów ${ }^{19}$. Mając powyższe na uwadze, przy podejmowaniu badań własnych w zakresie monitoringu losów zawodowych absolwentów szkoły wyższej uwzględniono stopień ukończenia studiów. Przeprowadzone badania pozwoliły dokonać analizy sytuacji ogółu absolwentów uczelni w momencie ukończenia studiów wyższych I i II stopnia, co stało się celem artykułu.

Należy nadmienić, iż autorzy opracowania od kilku lat podejmują problematykę bezpieczeństwa edukacyjnego absolwentów, zarówno w ujęciu sprofilowanym ${ }^{20}$, jak i ogólnym ${ }^{21}$.

\section{ORGANIZACJA BADAŃ}

W roku akademickim 2013/2014 studia wyższe w Państwowej Szkole Wyższej im. Papieża Jana Pawła II w Białej Podlaskiej ukończyło 640 absolwentów ${ }^{22}$. Autorski kwestio-

${ }^{16}$ Wojewódzki Urząd Pracy w Lublinie, Losy absolwentów szkót województwa lubelskiego. Raport z badań ilościowych wśród absolwentów szkót wyższych i jakościowych wśród absolwentów szkót ponadgimnazjalnych $i$ wyższych, Lublin 2014, s. 63.

17 Por. A. Dymicka, A. Smarzewska, E. Melaniuk, A. Szepeluk, Praktyki zawodowe jako element bezpieczeństwa edukacyjnego [w:] M. Kubiak, A. Smarzewska, Perspektywy bezpieczeństwa narodowego w XXI wieku, Biała Podlaska 2014, s. 141-153.

18 A. Smarzewska, E. Melaniuk, Kompetencje studentów kierunku bezpieczeństwo narodowe PSW w Biatej Podlaskiej, Kwartalnik Bellona 2014, nr 4, s. 185.

19 Bilans Kapitału Ludzkiego, Młodość czy doświadczenie? Kapitat ludzki w Polsce. Raport, Warszawa 2013, s. 124.

20 A. Smarzewska et al, Realizacja specjalności zarządzanie kryzysowe w perspektywie wejścia na rynek pracy jej absolwentów [w:] A. Polak, A. Smarzewska, P. Borek, Oblicza i wyzwania obronności w XXI wieku, Biała Podlaska 2015, s. 133-142.

21 A. Smarzewska, E. Melaniuk, Wptyw oceny na dyplomie na możliwość zatrudnienia absolwentów kierunku Bezpieczeństwo Narodowe, Rozprawy Społeczne 2014, nr 4 (VIII), s. 43-49; A. Smarzewska, E. Melaniuk, Bezpieczeństwo edukacyjne absolwentów szkót ponadgimnazjalnych z powiatu bialskiego i miasta Biała Podlaska zapewniane przez. PSW im. Papieża Jana Pawta II w Białej Podlaskiej w latach 2010-2012, Rozprawy Społeczne 2013, nr 2 (VII), s. 163-174.

${ }^{22}$ Na podstawie Sprawozdania o studiach wyższych S-10 według stanu w dniu 30.11.2014 r., GUS. 
nariusz ankiety absolwenta PSW ${ }^{23}$ wypełniło 487 osób, co stanowiło 76,1\% ogółu. Należy zaznaczyć, iż uczestnictwo absolwentów w badaniu było dobrowolne, poprzez złożenie deklaracji zgody na udział w Monitorowaniu Karier Zawodowych Absolwentów ${ }^{24}$. Uwzględniając płeć badanych kobiety stanowiły 66,7\% ogółu, a mężczyźni 33,3\%; miejsce zamieszkania - zarówno absolwenci z obszarów wiejskich, jak i miast (odpowiednio 48,4\% i 47,1\%); poziom studiów - liczba absolwentów studiów I stopnia była trzy razy większa, niż absolwentów studiów II stopnia (odpowiednio $73,1 \%$ oraz $26,9 \%$ ).W badaniu udział wzięło $4,5 \%$ obcokrajowców.

Badanie przeprowadzono od czerwca do listopada 2014 roku. W programie STATISTICA10, przy wykorzystaniu testu Chi kwadrat Pearsona, zbadano zależności pomiędzy zmiennymi. We wszystkich analizowanych przypadkach przyjęto poziom istotności $\mathrm{p}=0,05$, a odpowiedzi istotne statystycznie oznaczono gwiazdką (*).

\section{PREZENTACJA WYNIKÓW BADAŃ WŁASNYCH}

W badaniach uwzględniono problematykę dotyczącą oceny studiów, warunków studiowania, opinii absolwentów w zakresie szans na rynku pracy, stopnia opanowania kompetencji niezbędnych na rynku pracy oraz zgodności programu kształcenia z oczekiwaniami absolwentów. Uzyskane wyniki pozwolą w procesie planowania celów taktycznych i operacyjnych uwzględnić działania służące zapewnieniu wysokiej jakości kształcenia, poprzez weryfikację programów kształcenia w oparciu o potrzeby rynku pracy.

W grupie badanych absolwentów ocena dotycząca ukończonych studiów wyższych była bardzo pozytywna. Blisko $90 \%$ wskazań respondentów odnosiło się odpowiednio do zgodności kierunku i specjalności studiów z zainteresowaniami oraz spełnienia oczekiwań w procesie kształcenia w zakresie wyboru studiów, co należy uznać za istotne z punktu widzenia uczelni. Absolwenci w znacznej większości ustosunkowali się do przygotowania do pracy zawodowej. Należy stwierdzić, iż w grupie blisko $82 \%$ ogółu badanych miało miejsce przekonanie o właściwym przygotowaniu do pracy zawodowej w trakcie studiów (rys. 1).

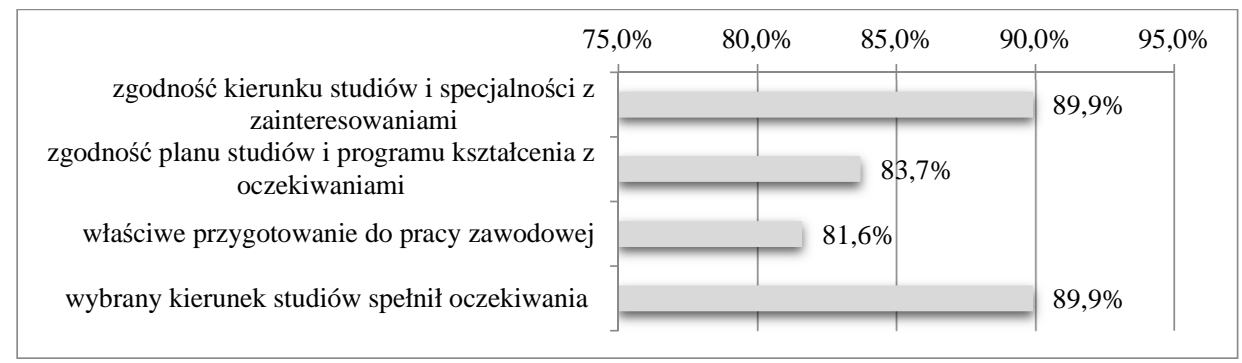

Rys. 1. Ocena studiów przez absolwentów

Źródło: opracowanie własne.

${ }^{23}$ Uchwała nr 53/2014 Senatu Państwowej Szkoły Wyższej im. Papieża Jana Pawła II w Białej Podlaskiej z dnia 27.06.2014 roku w sprawie: zatwierdzenia zmian załączników Wewnętrznego Systemu Zapewnienia Jakości Kształcenia w Państwowej Szkole Wyższej im. Papieża Jana Pawła II w Białej Podlaskiej, załącznik 7 do WSZJK.

${ }^{24}$ Tamże, załącznik 6 do WSZJK. 
Warto zaznaczyć, iż opinie absolwentów przedstawione na rys. 1 zostały poddane dalszej analizie statystycznej. Pozwoliło to poprzez zastosowanie testu Chi kwadrat Pearsona na zbadanie zależności pomiędzy omawianymi zmiennymi, a stopniem studiów I i II stopnia. W przypadku zdolności planu studiów i programu kształcenia z oczekiwaniami (rys. 2) stwierdzono zależność istotną statystycznie w odniesieniu do studiów I i II stopnia. W grupie absolwentów I stopnia studiów potwierdzona zgodność planu studiów i programu kształcenia z oczekiwaniami jest większa, niż w przypadku absolwentów studiów II stopnia (różnica na poziomie 8\%), co może świadczyć o lepszym dopasowaniu kształcenia na poziomie studiów I stopnia.

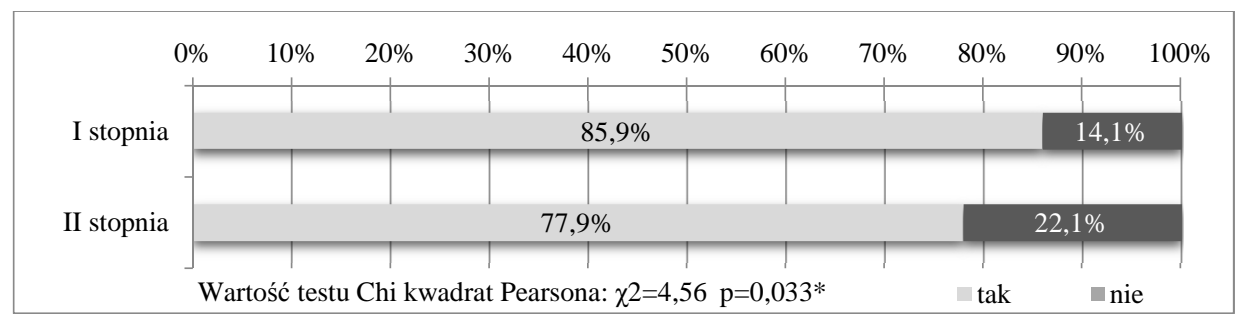

Rys. 2. Zgodność planu studiów i programu kształcenia z oczekiwaniami absolwentów z uwzględnieniem stopnia studiów

Źródło: opracowanie własne.

Odnosząc się do drugiej zmiennej, która także wykazała zależność istotną statystycznie, tj. spełnienie oczekiwań przez wybrany kierunek studiów (rys. 3) również absolwenci I stopnia studiów, częściej niż II stopnia, wskazują na zaspokojenie oczekiwań na wybranym kierunku studiów (różnica na poziomie 8,1\%).

W przypadku pozostałych zmiennych, tj. zgodność kierunku i specjalności studiów z zainteresowaniami oraz właściwego przygotowania do pracy zawodowej nie stwierdzono zależności istotnych statystycznie w odniesieniu do stopnia studiów.

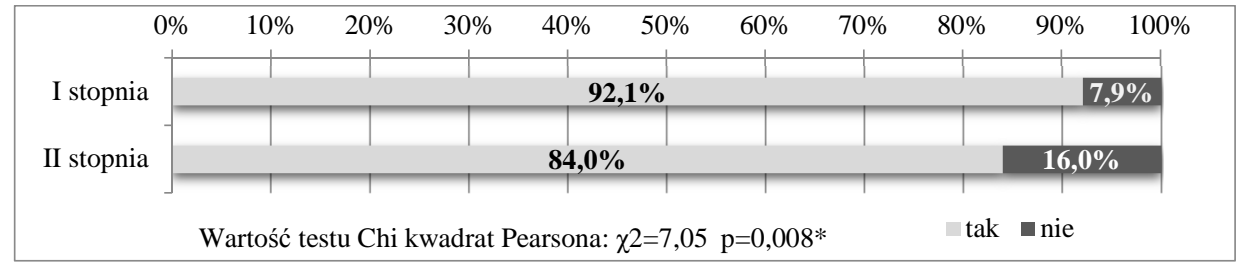

Rys. 3. Spełnienie oczekiwań absolwentów przez wybrany kierunek z uwzględnieniem stopnia studiów

Źródło: opracowanie własne.

Podobne działania, tj. badanie zależności zmiennych, podjęto w przypadku zalet zdobytego wykształcenia w odniesieniu do stopnia studiów (rys. 4). W grupie odpowiedzi dominowały takie, jak zwiększenie szans na rynku pracy (średnio 53,2\% wskazań) oraz możliwość kontynuacji nauki i dalszego kształcenia (średnio $46 \%$ odpowiedzi). Ważnym 
efektem badawczym jest obserwacja, iż absolwenci w minimalnej liczbie wskazań (średnio na poziomie 3,5\%) stwierdzali, że zdobyte wykształcenie nic nie zmieni. Co ważne, obie zmienne o największej liczbie wskazań wykazują zależność istotną statystycznie. W przypadku absolwentów studiów I stopnia (55,1\% wskazań) możliwość kontynuacji nauki i dalszego kształcenia jest ważniejsza, niż w grupie absolwentów studiów II stopnia $(21,4 \%)$. $\mathrm{Z}$ kolei wzrost szans na rynku pracy ma większe znaczenia dla tej grupy absolwentów $(64,1 \%)$, niż dla badanych po ukończeniu studiów I stopnia $(49,2 \%)$. Niemniej jednak warto podkreślić, że obie grupy absolwentów (po studiach I i II stopnia) w liczbie co najmniej połowy badanych wskazują na to, iż szanse na rynku pracy są większe dzięki zdobytej edukacji.

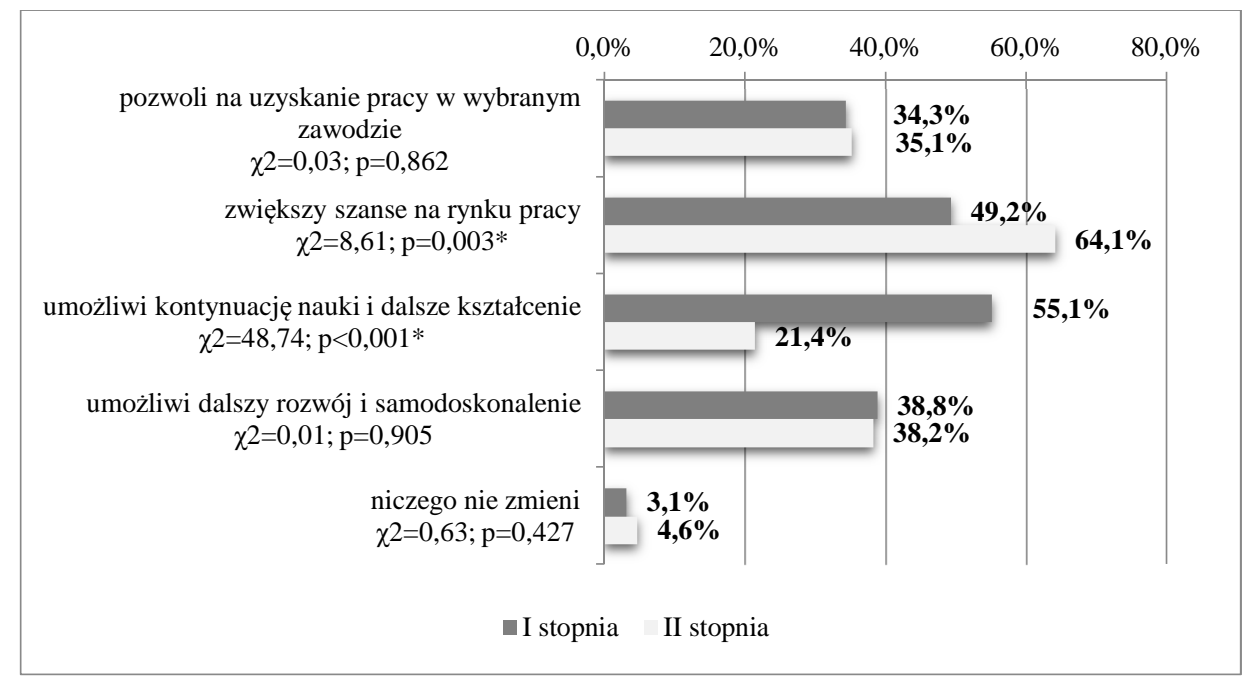

Rys. 4. Zalety zdobytego wykształcenia z uwzględnieniem stopnia studiów

Źródło: opracowanie własne.

Zdaniem badanych wzrost szans na rynku pracy jest elementem m.in. nauki i rozwoju kompetencji (rys. 5) oraz warunków studiowania (rys. 6). Zastosowano skalę ocen od 1 do 5 , gdzie 1 było wartością minimalna, a 5 - maksymalną. Absolwenci jako wiodące kompetencje, które opanowali w najwyższym stopniu w trakcie kształcenia wskazali na umiejętność współpracy (średnia ocena 4,38), podejmowanie decyzji $(4,26)$, kreatywność $(4,25)$ oraz asertywność $(4,24)$ i umiejętność komunikowania $(4,23)$. Co istotne, w grupie wskazań kompetencji, wszyscy badani posiedli je na poziomie co najmniej 3,83, co stanowiło najniższą uzyskaną wartość, odnoszącą się do przywództwa.

W przypadku warunków studiowania najwyżej oceniono poziom zajęć dydaktycznych (średnia ocena 4,21) oraz dostępność informacji $(4,17)$ i bazę materialną uczelni $(4,15)$. Badani najsłabiej spośród możliwych odpowiedzi do wyboru ocenili wspieranie ich rozwoju osobistego - na poziomie 3,97 . 


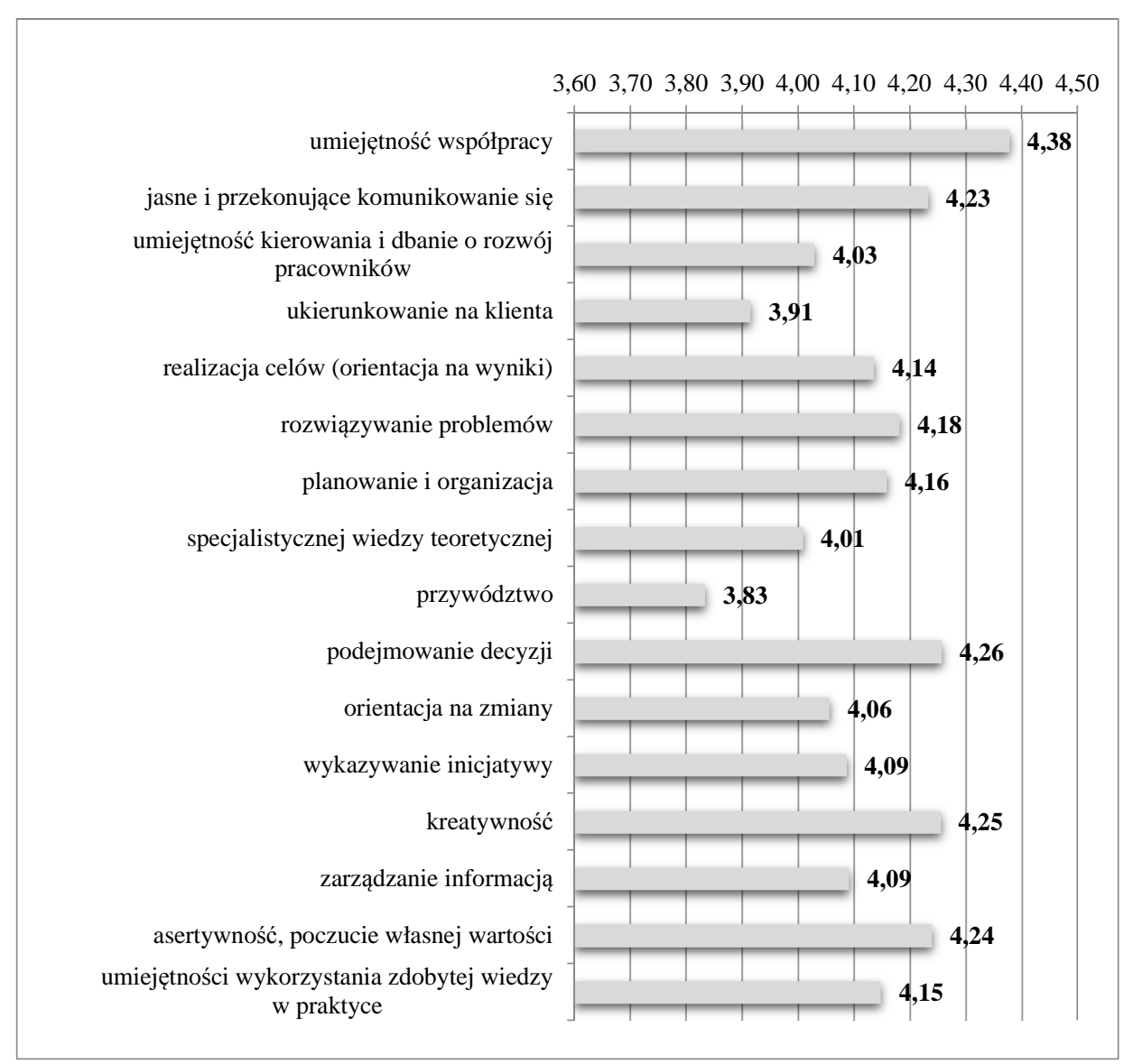

Rys. 5. Stopień opanowania kompetencji przez absolwentów

Źródło: opracowanie własne.

W związku z powyższym zapytano respondentów o wskazanie obszarów w ofercie edukacyjnej, społecznej i kulturalnej uczelni, które należałoby udoskonalać (rys. 7). Absolwenci wyróżnili trzy główne działania: organizację spotkań z ciekawymi ludźmi (blisko $45 \%$ ), organizację kursów językowych $(42,3 \%)$ oraz organizację wyjazdów studyjnych/wycieczek naukowych $(40,7 \%)$.

Co istotne, w grupie działań, które wskazała niewielka liczba (mniej, niż 10\% badanych) znalazły się takie działania, jak prace w samorządzie studenckim $(3,5 \%)$, przedstawienia teatralne $(5,5 \%)$ oraz wolontariat $(9,9 \%$ wskazań), co może oznaczać, iż te działania są w pełni realizowane przez uczelnię i nie należy nic udoskonalać lub działania te nie mają znaczenia w opinii badanych absolwentów. 


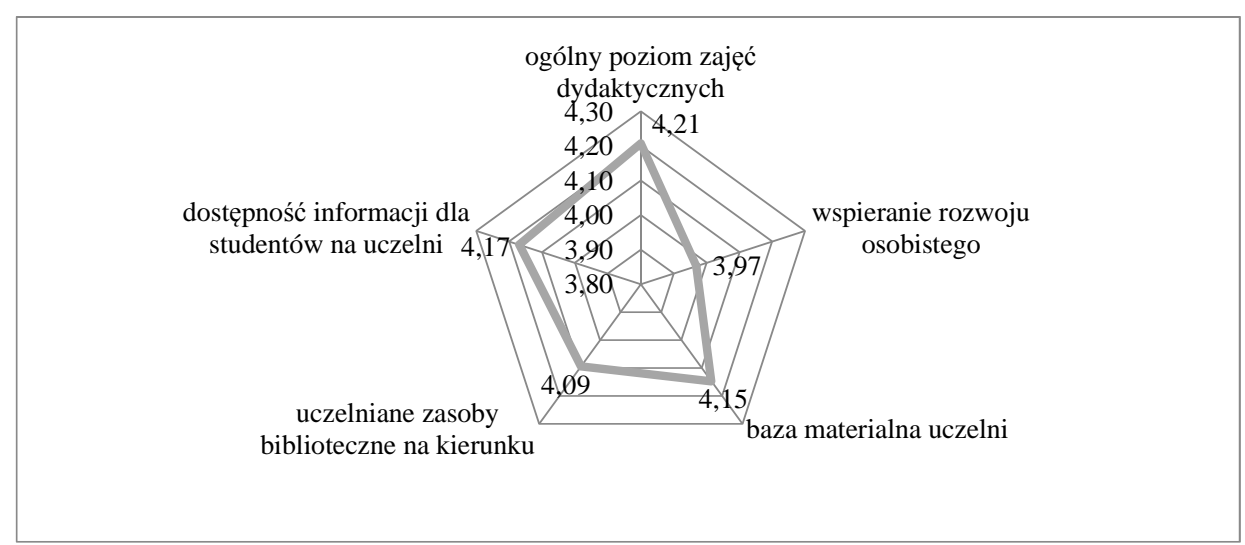

Rys. 6. Warunki studiowania na uczelni

Źródło: opracowanie własne.

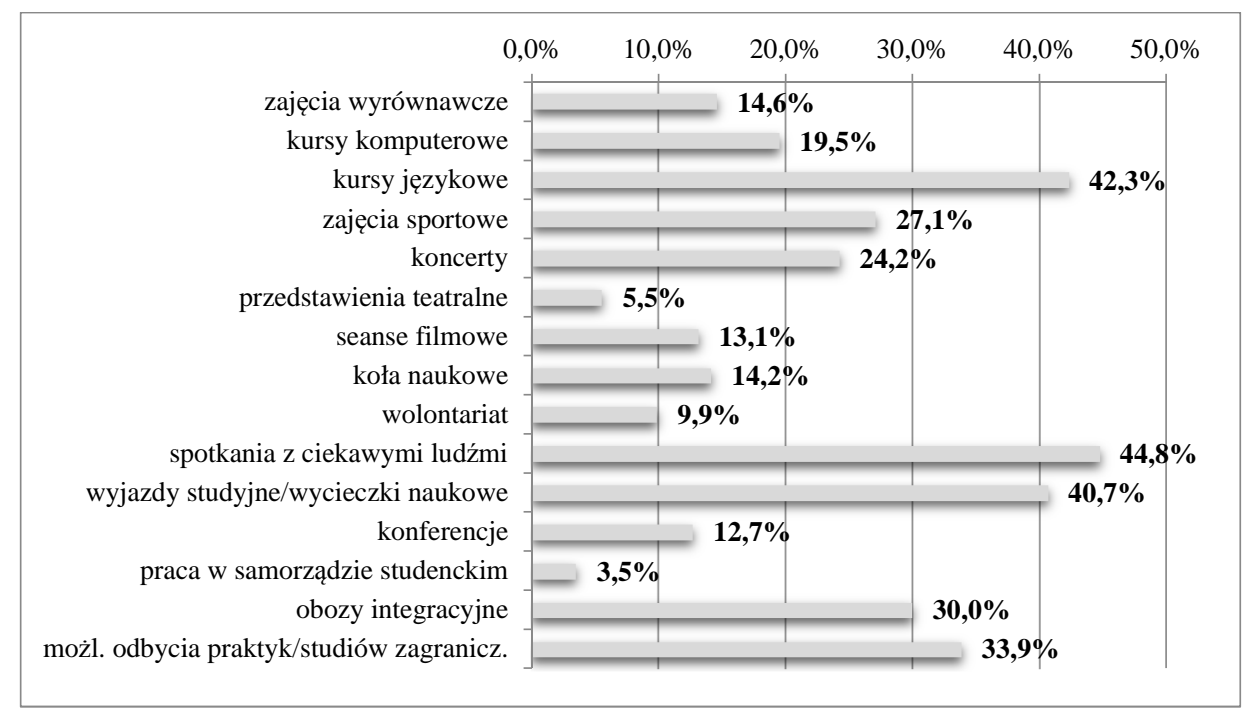

Rys. 7. Działania, które należałoby ulepszyć w ofercie edukacyjnej, społecznej i kulturalnej uczelni Źródło: opracowanie własne.

W odniesieniu do planów po ukończeniu studiów absolwenci chcą kontynuować naukę lub szukać pracy (odpowiednio średnie wartości 42,9\% oraz 44,4\%). Należy stwierdzić, iż w grupie absolwentów plany posiadają prawie wszyscy badani $(98,4 \%)$. Tylko co dziesiąty absolwent rozważa wyjazd za granicę lub rozpoczęcie własnej działalności gospodarczej (rys. 8). 


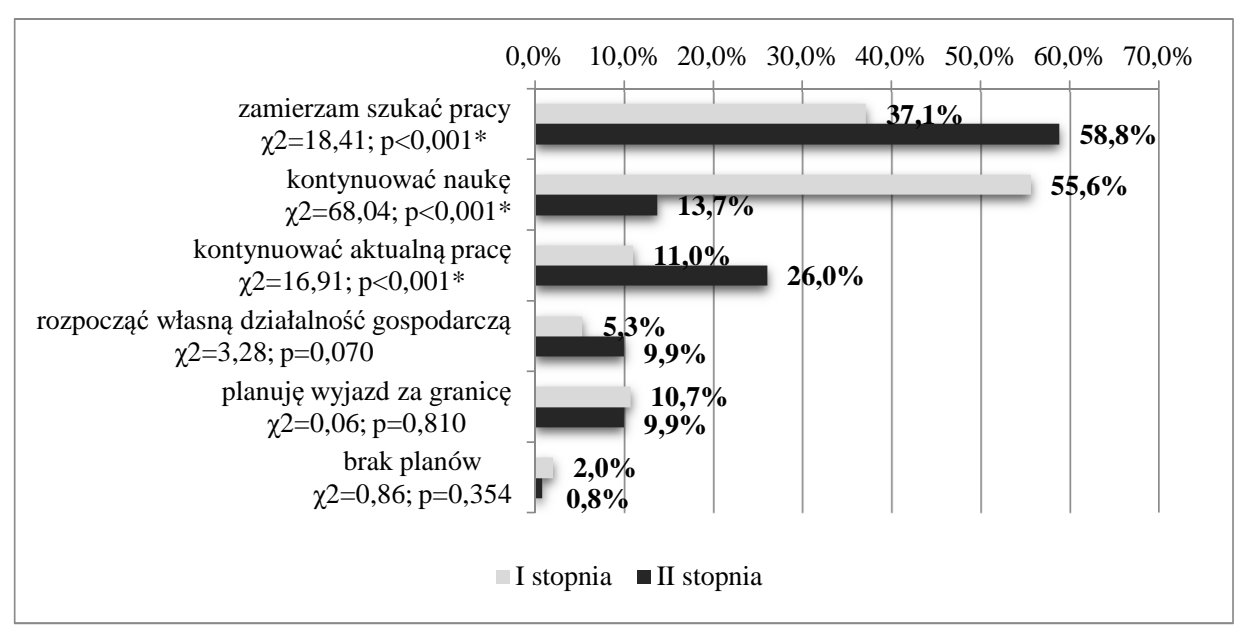

Rys. 8. Plany absolwentów po ukończeniu studiów z uwzględnieniem stopnia studiów Źródło: opracowanie własne.

Po zastosowaniu testu Chi kwadrat Pearsona zbadano zależność zmiennych takich jak: plany po ukończeniu studiów a stopień studiów, które wykazały zależność istotną statystycznie w przypadku trzech odpowiedzi, tj. szukania pracy, kontynuacji nauki oraz kontynuacji aktualnej pracy. Uzyskane wartości w odniesieniu do wskazanych zmiennych są zależne od stopnia studiów. Absolwenci studiów I stopnia przede wszystkim, w ponad połowie wskazań $(55,6 \%)$, chcą kontynuować naukę (absolwenci studiów II stopnia tylko $13,7 \%$ ) oraz szukać pracy 37,1\%. Natomiast absolwenci studiów II stopnia zamierzają szukać pracy (blisko $60 \%$ badanych) lub kontynuować pracę już posiadaną (26,0\%). Potwierdza to wnioski z raportu Bilansu Kapitału Ludzkiego ${ }^{25}$, stwierdzające różnicowanie szans na rynku pracy w odniesieniu do ukończonego stopnia studiów.

\section{PODSUMOWANIE I WNIOSKI}

Mając na uwadze wielowymiarowy charakter bezpieczeństwa ${ }^{26}$ należy przyjąć, iż w jeden z jego wymiarów wpisuje się problematyka podjęta w artykule. Tytułowe bezpieczeństwo zawodowe w odniesieniu do absolwenta uczelni wyższej można postrzegać jako stan gwarancji sukcesu na rynku pracy. Zdobyte wykształcenie, które jest efektem kształtowania bezpieczeństwa edukacyjnego staje się elementem mającym zapewnić powodzenie w zatrudnieniu. Przyjęte założenia artykułu, uwzględniające stopień studiów poprzez przeprowadzone analizy, pozwalają na wysunięcie wniosków z badań:

1. Ponad $80 \%$ absolwentów potwierdziło zgodność planu studiów i programu kształcenia z ich zainteresowaniami oraz oczekiwaniami, kształtując jednoznacznie pozytywną opinię badanych w odniesieniu do oceny studiów.

${ }^{25}$ Bilans Kapitału Ludzkiego, Młodość czy doświadczenie? Kapitat ludzki w Polsce. Raport, Warszawa 2013.

${ }^{26}$ L.F. Korzeniowski, Podstawy nauk o bezpieczeństwie. Zarzadzanie bezpieczeństwem, Warszawa 2012, s. 76. 
2. Ponad $80 \%$ absolwentów jest przekonanych o właściwym przygotowaniu do pracy zawodowej.

3. Istnieje zależność istotna statystycznie w badanej grupie absolwentów, która odnosi się do zgodności planu studiów i programu kształcenia z ich oczekiwaniami oraz że wybrany kierunek studiów spełnił oczekiwania absolwentów, przy uwzględnieniu studiów I i II stopnia. W przypadku obu wskazanych zmiennych, absolwenci studiów I stopnia (na poziomie wyższym o $8 \%$ od grupy absolwentów studiów II stopnia) częściej je wskazywali.

4. Główną zaletą zdobytego wykształcenia zdaniem absolwentów jest wzrost szans na rynku pracy (co najmniej połowa badanych).

5. Realizacja zakładanych programów kształcenia wpłynęła na dobre opanowanie kompetencji w opinii badanych. Najlepiej rozwiniętą kompetencją ich zdaniem jest umiejętność współpracy, opanowana na poziomie 4,38 w skali 1 (min) - 5 (max).

6. W grupie warunków studiowania na uczelni najwyżej oceniono poziom zajęć dydaktycznych $(4,21)$ w skali 1 ( $\min )-5(\max )$.

7. Absolwenci zastrzegają konieczność ulepszania oferty edukacyjnej, społecznej i kulturalnej uczelni, głównie poprzez organizację spotkań z ciekawymi ludźmi, kursów językowych oraz wycieczek naukowych/studyjnych.

8. Plany absolwentów są zróżnicowane ze względu na stopień ukończonych studiów. Absolwenci studiów I stopnia chcą przede wszystkim kontynuować naukę (55,6\%), natomiast absolwenci studiów II stopnia zamierzają szukać pracy (blisko 60\%). Warto zauważyć, iż w grupie absolwentów studiów I stopnia co trzeci badany także planuje poszukiwanie pracy.

Przedstawione wnioski kształtują pozytywną opinię absolwentów w zakresie wszystkich obszarów objętych badaniami, potwierdzając tym samym poprawność prowadzonej polityki uczelni i działań budujących bezpieczeństwo edukacyjne. Niemniej jednak jest to badanie diagnozujące punkt wyjścia absolwenta z uczelni, które należy kontynuować. W odstępie roku, trzech oraz pięciu lat od ukończenia studiów wyższych respondenci uczestniczący w badaniach, będących przedmiotem artykułu, ponownie się wypowiedzą tym razem w zakresie aktywności zawodowej. Przygotowane narzędzie badawcze, stanowiące załącznik 8 do WSZJK ${ }^{27}$ pozwoli na monitoring ich karier zawodowych.

Prezentowane wyniki badań są zatem częścią cyklu badawczego z zakresu bezpieczeństwa edukacyjnego, uwzględniającego szereg tworzących je elementów, m.in. badania studentów I roku w zakresie wyboru uczelni oraz kierunku studiów, badania opinii pracodawców pod kątem oceny studentów odbywających praktyki zawodowe czy monitoringu karier zawodowych absolwentów. Realizacja cyklu rozpoczęła się od 2013 roku i jest prowadzona aktualnie, przyczyniając się do zapewnienia bezpieczeństwa edukacyjnego poprzez podnoszenie jakości kształcenia oraz w efekcie finalnym - osiągnięcie aktywności zawodowej absolwentów.

\section{LITERATURA}

[1] Bilans Kapitału Ludzkiego, Młodość czy doświadczenie? Kapitał ludzki w Polsce. Raport, Warszawa 2013.

[2] CBOS, Postawy prokreacyjne Polaków BS/4/2010, Warszawa 2010.

\footnotetext{
27 Tamże, załącznik 8 do WSZJK.
} 
[3] CBOS, Studia wyższe - dla kogo, po co i z jakim skutkiem BS/92/2013, Warszawa 2013.

[4] Dymicka A., Smarzewska A., Melaniuk E., Szepeluk A., Praktyki zawodowe jako element bezpieczeństwa edukacyjnego [w:] M. Kubiak, A. Smarzewska, Perspektywy bezpieczeństwa narodowego w XXI wieku, Wyd. PSW JPII, Biała Podlaska 2014.

[5] Korzeniowski L.F., Podstawy nauk o bezpieczeństwie. Zarzadzanie bezpieczeństwem, Difin, Warszawa 2012.

[6] Krzesiński, Dziś - przemyślany wybór kierunku studiów, w przyszłości-większa szansa na dobra pracę, Biuletyn Informacyjny Wojewódzkiego Urzędu Pracy w Lublinie „Lubelskie na rynku pracy", nr 3/12, Lublin 2014.

[7] Ministerstwo Pracy i Polityki Społecznej, Sytuacja na rynku pracy osób młodych w 2014 roku, Warszawa 2014.

[8] Ministerstwo Pracy i Polityki Społecznej, Zawody deficytowe i nadwyżkowe w 2014 roku, Warszawa 2015.

[9] Piotrowska D., Ziółek M., Wewnętrzne systemy zapewnienia jakości kształcenia w odniesieniu do nowych regulacji prawnych, Łódź 2012, http://ekspercibolonscy.org.pl (dostęp: 08.07.2015 r.).

[10] Pracownia Ewaluacji Jakości Kształcenia Uniwersytetu Warszawskiego, Monitorowanie losów absolwentów uczelni wyższych z wykorzystaniem danych administracyjnych Zakładu Ubezpieczeń Społecznych. Raport końcowy, IBE, Warszawa 2014.

[11] Próchnicka M., Zeszyt dobrych praktyk dotyczacych wewnętrznego zapewnienia jakości ksztatcenia w uczelniach, Fundacja Rozwoju Systemu Edukacji, Warszawa 2013.

[12] Rzecznik Praw Absolwenta, Akademickie Biura Karier w Polsce bieżąca działalność i możliwości rozwoju, Warszawa 2014.

[13] Smarzewska A., Melaniuk E., Bezpieczeństwo edukacyjne absolwentów szkót ponadgimnazjalnych z powiatu bialskiego i miasta Biała Podlaska zapewniane przez PSW im. Papieża Jana Pawta II w Biatej Podlaskiej w latach 2010-2012, Rozprawy Społeczne 2013, nr 2 (VII).

[14] Smarzewska A., Melaniuk E., Dymicka A., Szepeluk A., Realizacja specjalności zarządzanie kryzysowe $w$ perspektywie wejścia na rynek pracy jej absolwentów [w:] A. Polak, A. Smarzewska, P. Borek, Oblicza i wyzwania obronności w XXI wieku, Wyd. PSW JPII, Biała Podlaska 2015.

[15] Smarzewska A., Melaniuk E., Kompetencje studentów kierunku bezpieczeństwo narodowe PSW w Białej Podlaskiej, Kwartalnik Bellona 2014, nr 4.

[16] Smarzewska A., Melaniuk E., Wpływ oceny na dyplomie na możliwość zatrudnienia absolwentów kierunku Bezpieczeństwo Narodowe, Rozprawy Społeczne 2014, nr 4 (VIII), s. 43-49.

[17] Uchwała nr 53/2014 Senatu Państwowej Szkoły Wyższej im. Papieża Jana Pawła II w Białej Podlaskiej z dnia 27.06.2014 roku w sprawie: zatwierdzenia zmian załączników Wewnętrznego Systemu Zapewnienia Jakości Kształcenia w Państwowej Szkole Wyższej im. Papieża Jana Pawła II w Białej Podlaskiej, załączniki 6, 7, 8 do WSZJK.

[18] Ustawa z dnia 11 lipca 2014 r. o zmianie ustawy - Prawo o szkolnictwie wyższym oraz niektórych innych ustaw (Dz.U. z 2014 r. poz. 1198 ze zm.).

[19] Ustawa z dnia 18 marca 2011 r. o zmianie ustawy - Prawo o szkolnictwie wyższym, ustawy o stopniach naukowych i tytule naukowym oraz o stopniach i tytule w zakresie sztuki oraz o zmianie niektórych innych ustaw (Dz.U. nr 84, poz. 455 ze zm.). 
[20] Wojewódzki Urząd Pracy w Lublinie, Losy absolwentów szkót województwa lubelskiego. Raport z badań ilościowych wśród absolwentów szkót wyższych i jakościowych wśród absolwentów szkót ponadgimnazjalnych i wyższych, Lublin 2014.

\section{FORMING OF THE GRADUATES' PROFESSIONAL SAFETY}

Chances of the placement are growing along with obtaining a university degree. Providing the occupational safety for graduates constitutes one of basic action shaped by the educational safety. Monitoring professional careers of graduates is desired with functioning of the school, translating into the update of the realized strategy. This article aims to analyze the situation of graduates after finishing education at the undergraduate level and postgraduate level. A statement that the higher education is lengthening the odds on the employment is an effect of survey, and the program carried out in the course of studies of the education enables due preparing for the transition to the labour market. The survey confirmed that the degree of completed studies was a factor diversifying professional chances of graduates of the college. Made conclusions are shaping the positive opinion of graduates in all areas provided with the survey, confirming the correctness of the pursued politics of the college and action creating the educational safety in the process. Over the $80 \%$ of graduates are convinced of the due preparation for the career. According to graduates' an increase in the labour market opportunities is a major advantage of the get education. Graduates are reserving the need to modify the college offer of the educational, social and cultural areas, mainly through the organization of meetings with interesting people, language courses and scientific trips. And so presented findings are a part of the research cycle from the margin of safety educational, taking into account the row of elements forming them, among others examining students at the beginning in choice of college and course degree, of opinion poll of employers in terms of the assessment of students undergoing traineeships or the monitoring of professional careers of graduates.

Keywords: safety, graduate, labor market, degree system.

DOI:10.7862/rz.2017.hss.37

Przestano do redakcji: czerwiec $2016 r$.

Przyjęto do druku: czerwiec 2017 r. 
